Engineering Sustainability

Volume 168 Issue ES4

Delivering Crossrail, UK: a holistic approach to sustainability

de Silva and Paris
Proceedings of the Institution of Civil Engineers Engineering Sustainability 168 August 2015 Issue ES4 Pages 151-158 http://dx.doi.org/10.1680/ensu. 1400037

Paper 1400037

Received 11/08/2014 Accepted 09/03/2015

Received $11 / 08 / 2014$
Published online 16/07/2015

Keywords: corporate responsibility/management/sustainability
,

\title{
Delivering Crossrail, UK: a holistic approach to sustainability
}

Michael de Silva PhD, FCIWEM, MIEEM, CWEM, CSci

Crossrail Sustainability Manager, Bechtel Ltd, London, UK
Robert Paris MSC, MCIWEM, MIES

Head of Sustainability \& Consents, 2Crossrail Ltd, London, UK

The sustainability strategy for delivering the $\mathbf{f} 15$ billion Crossrail cross-London railway project in the UK sets out the key sustainability themes that are material to delivery of the project and identifies key performance indicators to be used to track performance. The strategy adopts a holistic approach, taking a balanced view on environmental, social and economic performance. Whereas many projects have focused on the environmental aspects of sustainability, Crossrail is addressing issues of supply chain and small and medium enterprise engagement, supply chain risk management, local employment, skills and training, and ensuring that opportunities are not confined to the southeast of England. This paper will be of particular interest to client organisations responsible for national infrastructure but also provides valuable information for designers and construction professionals. The paper starts by providing a brief description of the scope of the project then describes how sustainability has been built into the delivery of the project, the governance structure and how performance is measured. Examples are provided of some of the key enablers and tools used on the project.

\section{The Crossrail project}

At $£ 15$ billion, the Crossrail cross-London railway project is the largest infrastructure project in Europe and forms a major part of the Mayor of London's transport strategy. Crossrail will connect 37 stations, including Heathrow airport and Maidenhead in the west with Canary Wharf, Abbey Wood and Shenfield in the east. Using the service will make travelling in the region easier and quicker and help to reduce crowding on London's transport network. As a public transport project, Crossrail delivers sustainable outcomes by

- relieving overcrowding on existing underground and train services

- adding $10 \%$ extra rail capacity for London

- decreasing journey times across London.

Crossrail brings an additional 1.5 million people within $45 \mathrm{~min}$ commuting distance of London's key business districts and around 200 million passengers will travel on it each year. Eight new subsurface stations will be connected by new twin-bore tunnels measuring $21 \mathrm{~km}$ in length under London.

Crossrail will deliver substantial economic benefits to London and across the UK. Crossrail has let some of the largest value contracts in recent UK construction history, providing a much-needed boost to UK industry and creating major employment opportunities. During the construction phase alone, the project will generate thousands of jobs, peaking at 55000 . It will also require the services of regionally based manufacturers and other suppliers. The estimated benefit to the UK economy is at least $£ 42$ billion over a 60 -year period.

\section{Building sustainability into the project}

In order to ensure that sustainability was integrated into business planning, an important first step was to produce a sustainability strategy. The strategy sets out a definition of sustainability for the project that is inclusive and far-reaching and began with a review of the themes reflected by the project sponsors, Transport for London (TfL) and the Department for Transport (HM Government, 2005). The themes were deemed relevant to the project and, in all, seven were adopted. Six of the Crossrail sustainability themes are seen to align closely with those for TfL, the arm of the Greater London Authority (GLA) charged with running London's transport network. The seventh - sustainable consumption and production - although not directly linked to the project sponsor themes, reflects an additional material consideration that building Crossrail requires the use and final disposal of significant material resources.

As shown in Figure 1, 15 key sustainability initiatives (KSIs) were developed, each designed to deliver against the sustainability themes. In addition, there are three cross-cutting initiatives, the undertaking of which is relevant to the delivery of each of the KSIs. These are sustainability governance, learning legacy and responsible procurement, as indicated by the arrows appended to the 'bubbles' on the right of Figure 1. Most of the KSIs identified are self-explanatory, but further elaboration on two of them is necessary.

- The art programme has become central to Crossrail as a world-class transport system and has been integrated into the development of the project as providing both an improved 


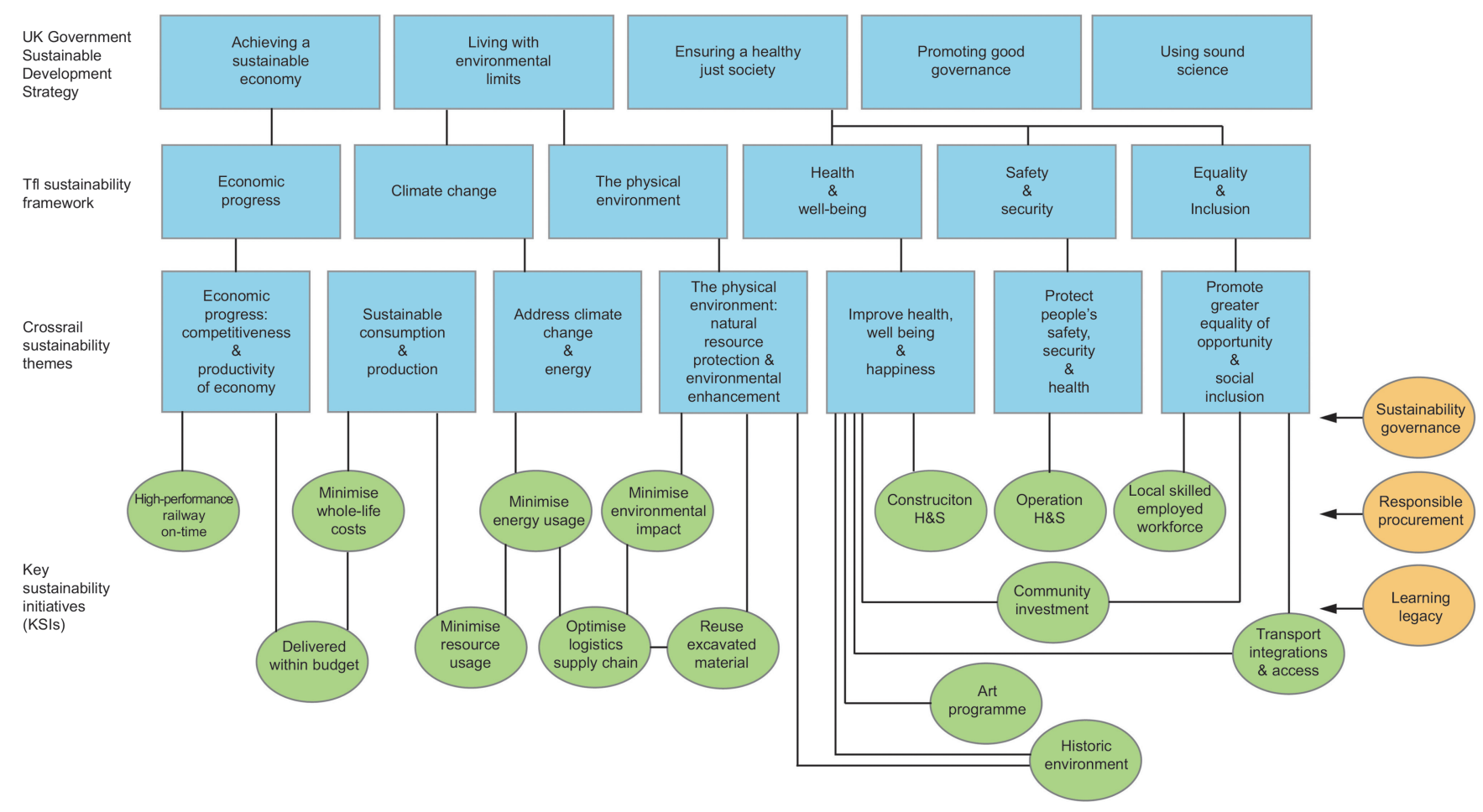

Figure 1. Crossrail's sustainability themes and key sustainability initiatives as defined in its strategy

passenger experience, while allowing a showcase for artists and new media such as digital art forms.

- Historic environment considers both archaeology and the existing built environment and is focused around the preservation of existing features, sympathetic design and the opportunity to discover more about London's past through investigation, recording, analysis and dissemination of information.

\section{Creating a sustainability governance structure and managing sustainability performance}

Responsibility for the realisation of each of the KSIs has been assigned to senior management under the overall direction of the chief executive. Each directorate is then either given or required to identify specific sustainability objectives and targets as part of the annual business plan, cascading these into individual objectives as required. Each year, corporate key performance indicators (KPIs) are established against which top-level management and partner organisations are financially incentivised, of which a large proportion are set to attain a high level of sustainability performance.

KPIs are developed for each KSI reported in three dashboards - one each for social, environmental and economic sustainability - and monitored on a quarterly basis by the sustainability committee, chaired by the chief executive, with other members including the programme director, delivery director, finance director, talent and resources director and several non-executive directors. The committee provides overall sustainability governance, promotes achievement of the sustainability objectives, and supports crossproject sustainability initiatives and those responsible for carrying them out, providing oversight, guidance and escalation routes if required; these can be at a project level with contractor project directors or elevated to corporate level depending on the level of concern with regard to performance. Every year, the committee reviews the overall sustainability performance and signs off publication of the annual sustainability report.

Sustainability performance is also included within a supplier performance framework (Figure 2). The framework is used to evaluate contractor performance against a series of criteria in the aspects of project delivery identified in the figure. The scores are combined and mapped in order to evaluate overall contractor performance. Performance is identified as non-compliant (with the requirements of the works information), compliant, beyond expectations or world-class. This assessment is undertaken twice yearly and any given contractor can view their performance against their anonymised competitors. The criteria and thresholds have been agreed with the project's contractors and the exercise is undertaken by Crossrail's internal performance assurance team. Over successive evaluation periods, the assurance framework has shown an improvement in overall averaged performance, and improvement in the performance of many of the individual contracts in a number of the assessed areas. It should be noted that 'commercial' is a reference to the commercial performance of the contractor and 'target zero' is the project's health and safety campaign. 


\section{Are we getting better?}

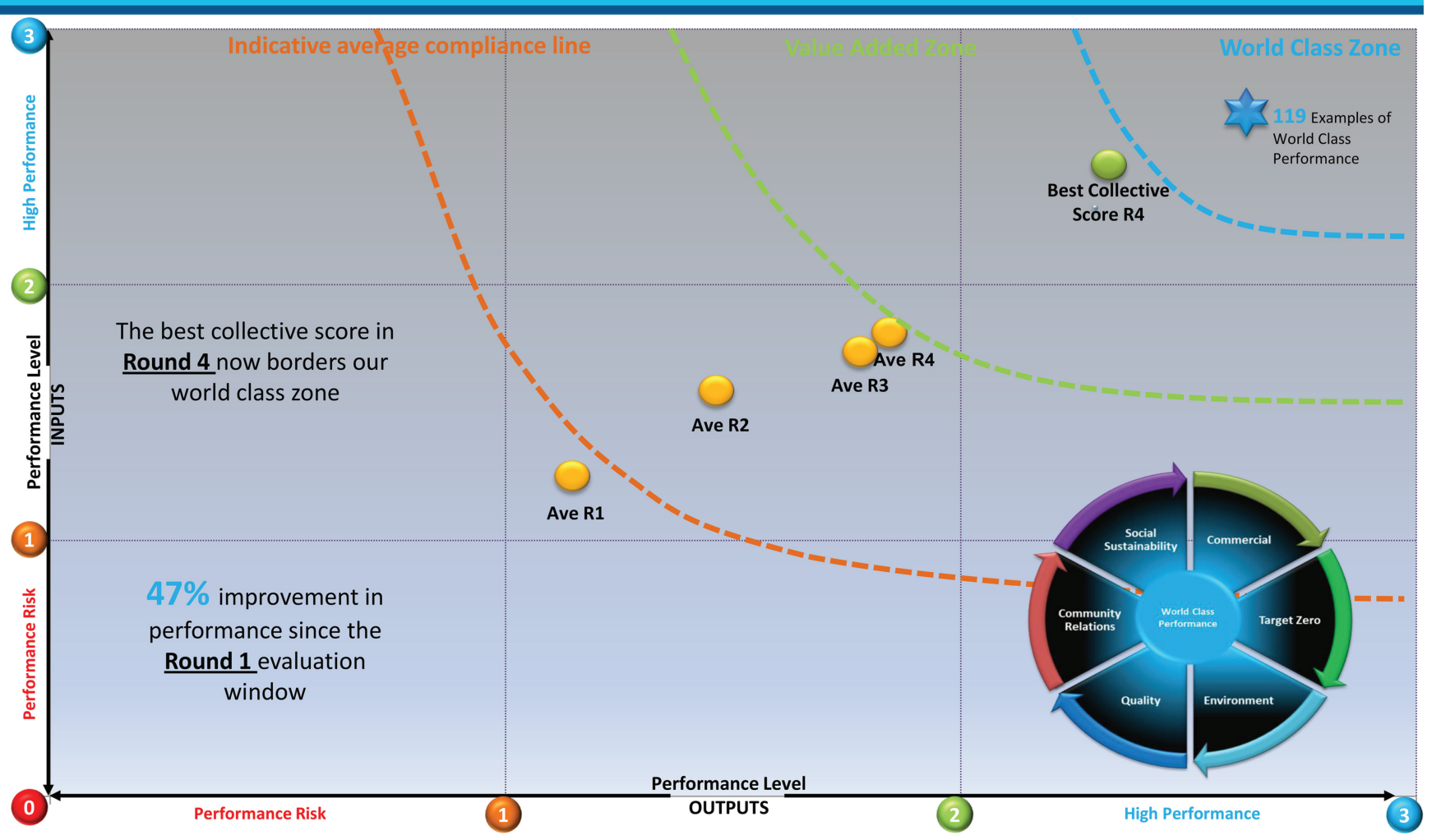

Figure 2. Supplier performance framework scores

For example, in considering environmental sustainability performance, the evaluation is carried out against environmental audits and inspections, incidents, training and awareness, air quality management, water management, energy and carbon dioxide management.

The framework has slowly been embraced by the project's contractors who are recognising that it is helping to drive better performance. Interest in the framework has been shown by other major projects in the UK, and it may thus become an important aspect of the project legacy.

\section{Sustainability policies and how they drive best practice}

Crossrail's commitment to sustainability is further underpinned by a number of key policies - the environment, carbon footprint, equality and dignity, health and safety, inclusivity and whole-life costing. Furthermore, the procurement strategy embodies the seven themes of responsible procurement as defined by the GLA (2008) and these in turn are articulated within the contracts with principal contractors. Reporting is required on a four-weekly or quarterly basis depending on the particular performance measure. The seven themes are
- encouraging a diverse base of suppliers

- promoting fair employment practices

- promoting workforce welfare

- addressing strategic labour needs and enabling training

- community benefits

- ethical sourcing practices

- promoting greater environmental sustainability.

Sustainability requirements have been written into all contracts in line with the themes and KSIs within the sustainability strategy. Examples of the policy requirements that have been cascaded to contractors within the works information that forms part of the contractual documentation include the following.

- Environmental requirements contained within the works information include a number of minimum performance levels in addition to specific targets. These requirements are extensive and cover management of carbon dioxide and energy, noise and vibration, dust and air quality, pollution control, water and material resources, archaeology and historic environment.

- All contracts use Breeam (Building Research Establishment environmental assessment methodology) (for stations) or 
Ceequal (Civil Engineering Environmental Quality) award scheme (for tunnel, portals and shafts) as an environmental assessment methodology and benchmarking tool.

- All personnel employed on the project are to be paid the London living wage.

- Contractors must use CompeteFor, a national supply chain development service that matches buyers and suppliers to allow local business to compete for work and achieve good diversity practice.

- All contractors are required to produce community investment plans. This requirement is aimed at encouraging contractors to deliver time and money to good causes locally - putting something back into the communities where construction works are causing the most disruption.

- All contractors must register with the Considerate Constructors Scheme. The project average is $42 \cdot 5 / 50$ on the national scoring scheme (the national average is $34 \cdot 5 / 50$ ).

- Crossrail has set a target of 400 new apprenticeships (working on Crossrail for at least 16 weeks).

- Crossrail has established a free job brokerage service. Jobcentre Plus is working with contractors and with a network of local outreach agencies to identify and advertise job vacancies and help equip local people to compete for these opportunities.

- All tier 1 contractors are required to establish project bank accounts (PBAs) to pay subcontractors. Thus, balances can be monitored to ensure they are maintained at a low level, indicating that suppliers are being paid promptly (within $30 \mathrm{~d}$ ).

- Supply chain exposure is continually monitored to ensure that risk is spread and that suppliers have capacity to supply to the project and are not overly dependent on Crossrail as a sole or predominant customer.

Core elements of the works information are taken from the Crossrail environmental minimum requirements (EMRs). The EMRs are standards and procedures that have been agreed with local authorities and statutory agencies in order to control and manage environmental impacts. This includes the construction code, which explains how contractors' work will be controlled. The construction code represents best practice environmental management as established in the setting of these requirements in the 2008 Crossrail Act (2008).

\section{Working groups, fora and other enablers for industry best practice}

Contractual requirements alone are not going to deliver worldclass performance. The importance of having a common vision, a collaborative working environment and performance incentives is also vital in ensuring successful outcomes. Collaborative working and information sharing in order to accelerate performance improvement has been promoted through a number of fora. For example, Crossrail runs the following.

- A contractor environmental managers' forum and collaboration website to share best practice and lessons learned across the programme of works.
- A project carbon working group, bringing together corporate sustainability managers from across the tier 1 contractors to work collaboratively and seek opportunities to deliver a lower carbon dioxide solution for Crossrail and share industry knowledge for future projects. A focus of this group is to demonstrate tangible links between lower carbon dioxide and lower cost.

- A project ethical sourcing working group, bringing together procurement specialists to address risk mitigation in the project's supply chains.

- An innovation club, the first of its kind for a temporary organisation.

\section{Measuring performance}

\subsection{Construction energy}

Discussion within the industry and notably Constructing Excellence (CE) highlights that there is little benchmark data for the heavy construction activities being undertaken on the project. CE is the single organisation, in the UK, charged with driving the change agenda in construction. It exists to improve industry performance in order to produce a better built environment. It is a cross-sector, cross-supply chain, member-led organisation operating for the good of industry and its stakeholders. The project is pioneering an approach to understand the entire carbon footprint of Crossrail over its 120-year operational life, including a focus on reducing construction energy. This has led to an average construction carbon dioxide reduction of $11 \%$ against a target of $8 \%$ across the programme. Crossrail data will be made available to the industry through CE. A number of spreadsheet-based macro calculations have been developed that can be used within the project's construction carbon footprint module so that the carbon dioxide reduction benefits of a particular technology or initiative can be immediately identified.

\subsection{Breeam and Ceequal}

As noted earlier, Crossrail uses two environmental sustainability evaluation schemes, Breeam and Ceequal.

Breeam is an environmental assessment method and rating system for buildings, with 250000 buildings with certified Breeam assessment ratings and over a million registered for assessment since it was first launched in 1990. Crossrail is the first project to utilise Breeam for the assessment of an underground station. Through collaboration with the Building Research Establishment (BRE), criteria were developed for underground stations and ready for use in late 2009. These are used in conjunction with Bespoke Breeam, launched in 2008. This is an industry-leading initiative which will allow benchmarking for underground stations including those on projects such as the Northern Line extension and High Speed 2.

Breeam pre-assessments were undertaken at Royal Institute of British Architects (RIBA) Stage C+, and used as a basis for stipulating a target Breeam rating of 'very good' for the completed stations. 
As with any new system, application of the underground station criteria has required continuing dialogue with the BRE. This has led to the removal of one credit from the original criteria, and the amendment of others, notably ENE 1, where a change was agreed for auxiliary energy value. As station designs were developed, it also became apparent that certain room types were not present in some stations, so the related credits were removed from the bespoke assessment for that particular building.

The Ceequal award scheme is being used to evaluate the project's tunnel, portal and shaft structures. The assessments have been split into an initial client and interim design award, all achieving 'excellent' ratings, and whole-project award ratings of excellent are targeted for the completed works. These have already been achieved for two completed structures, the Royal Oak portal near Paddington and the Paddington integrated project.

In retrospect, the decision to undertake the client and design interim stage assessment at what was effectively a RIBA stage D+ design has proved problematic: the requirement for the contractor to achieve a whole-project award that includes the client and design credits means that there is a need for continued client input into many of the credits. It is the authors' opinion that a more efficient division point would be to have a complete client and design award and a separate construction award.

It should be noted, however, that in a project of this size and complexity there will always be difficulties in establishing the optimal assessment boundaries. For example, design packages are not always aligned with construction procurement packages, and not all elements of design are completed when construction commences.

However, the use of these methodologies has provided a rigour to the evolving design process and has aided the focus on poorly performing areas such that improvements can be made. Contractor performance is also being measured through the use of Ceequal, which has a heavy points weighting on the physical construction process and environmental management thereof.

The transitioning of both the Breeam and Ceequal processes to contractors has encouraged them to seek areas for improvement. Performance is rewarded through the supplier performance framework and, of course, the recognition of obtaining the Breeam and Ceequal ratings themselves.

\subsection{Excavated material and construction waste}

Crossrail has set targets of $95 \%$ and $90 \%$ respectively for the diversion of excavated material and construction waste from landfill to beneficial use. The project is currently in excess of both of these targets, with nearly $100 \%$ of construction waste being diverted from landfill and $99 \%$ of excavated material being beneficially used, a significant volume of which is being used for the Wallasea Island wild coast project.
Wallasea Island, located on the Essex coast between the River Roach and River Crouch, will be transformed from levee-protected farmland into a thriving wetland, twice the size of the City of London and teeming with bird and marine life. The project, never before attempted on this scale in Europe, has been made possible through a partnership between the Royal Society for the Protection of Birds (RSPB). The loss of coastal habitat over the past four centuries has been dramatic. Without projects like Wallasea, rising sea levels are threatening to see another 1000 ha lost in the next decade. Wallasea will provide 670 ha of habitat for wetland wildlife to thrive and the RSPB predicts a significant increase in the number of birds once the project is completed. A long period of negotiation led to the development of waste acceptance criteria for material being transferred to the site. These criteria have to be strictly adhered to and a testing programme has being implemented to ensure that material is acceptable prior to its shipment.

\subsection{Diesel emissions control}

The project is committed to reduce emissions from non-road mobile machinery where reasonably practicable. The use of cleaner engines will contribute towards improving air quality in London, particularly for local communities.

Since 2010, Crossrail has been working with contractors to implement this requirement and to overcome concerns relating to equipment reliability, maintainability and adverse fuel consumption. By 2013/2014, 73\% of all plant used on the project had been fitted with diesel particulate filters (dpfs) or procured with more efficient and cleaner burning EU stage $3 \mathrm{~b}$ engines. Trials have shown that it is not practical to fit emissions controls (dpfs) to $19 \%$ of plant at this time (equating to $92 \%$ compliance). This programme has contributed to increasing the capacity and therefore the availability of dpf-fitted plant and new stage $3 \mathrm{~b}$ machinery to the London and southeast of England market.

\subsection{Economic growth, jobs and skills}

As the largest infrastructure project in Europe, Crossrail is helping to maintain and create jobs in the UK. Data representing 1751 contracts from tier 1 to tier 3 indicate that $62 \%$ of the project's supply chain spend is taking place outside of London, with $58 \%$ being small and medium enterprises (SMEs). Furthermore, 97\% of Crossrail-related contracts are being delivered by UK-based companies. These data have been used to map the geographic distribution of the supply chain, highlighting some of the specific opportunities being delivered around the UK. The project is expected to support the equivalent of 55000 full-time jobs right across the UK. Currently, three out of five of these jobs are outside of London and a similar proportion of this work is going to SMEs.

Another key objective for Crossrail has been to ensure engagement with the supply chain and, importantly, to try to create new opportunities for companies that may not otherwise have the 
opportunity to work on a programme such as Crossrail. The use of CompeteFor, an online resource that flags up potential contracts to these companies, has proved a successful tool in promoting opportunities and bringing new suppliers to the table. Given the opportunity to perform, there is every chance that these companies can become more regular members of the supply chain to the tier 1 contractors.

Contractors must ensure that their employees and those in their supply chains working on the project are being paid the London living wage. This is the hourly rate of pay set by the GLA based on the cost of living in London. Crossrail continues to work with its contractors to provide assurance that they and their supply chains are compliant with this commitment. The depth of the supply chain is such that Crossrail does not have absolute visibility of this across all contracts, but continues to support contractors in adopting more rigorous measures to increase this visibility and expose and rectify any non-compliance discovered.

Requirements for responsible procurement are as defined by the GLA's responsible procurement policy (GLA, 2008) and are cascaded through the works information. Contractors are required to produce a suite of plans that address the key aspects of skills and diversity. These are

- supplier diversity plan

- diversity training plan

- equality and diversity strategic plan

- strategic labour needs and training plan

- labour and skills gap plan.

\subsection{Community investment programme}

Projects such as Crossrail are built in the heart of a city and the impacts on local communities can thus be significant. Furthermore, the duration of the works means that contractors are very much part of the community for the duration of their tenure on the project. Contractors are required to develop a community investment plan that can include various initiatives. In some cases, this may simply be providing money for a community project, but more typically takes the form of donations of construction materials for community projects or volunteer time to assist on projects.

Crossrail Ltd, the client organisation, also has its own community investment programme, focusing on a number of schools in the area and linked in with the Young Crossrail initiative, an education programme for students. It targets both junior and senior school students with appropriate educational materials and was set up in response to the increasing challenge in the UK of attracting people to the engineering and construction industry. While the mission at Crossrail is to deliver a world-class railway for the twenty-first century, engineering also plays a key role in a broad range of industries outside the transport sector and this programme is designed to take this message out to local schools. Crossrail has a large number of volunteers from within the project who go out and work with local schools, but resources have also been developed for the schools to work on their own.

\subsection{Ethical sourcing}

The project also requires that, where practically possible, all construction materials are procured in accordance with the ethical trading initiative (ETI) base code. Certification systems that provide some degree of ethical screening of construction materials do exist (notably FSC/PEFC, BES6001 and UKCares Sustainability), but they do not provide the comprehensive coverage of issues as embodied in the ETI base code and as such should not be used as a proxy.

It therefore remains a challenge to the industry to seek ways in which global supply chains can be de-risked. This has been addressed by the project through the creation of a working group that is liaising closely with industry to identify and mitigate risk areas. Dialogue with trade associations and suppliers has aided this process, as has collaboration with the UK Contractors' Group, the Apres (Action Programme for Responsible Sourcing) network (managed by Loughborough University), the BRE and participation in several industry groups. The project has developed several resources, including a risk assessment framework, commodity and material sheets that detail issues of concern, and a best practice audit checklist that can be used by a supply chain partner to assess performance levels. The project also took the unprecedented step of making direct contact with mining organisations in order to establish a 'bottom-up' approach to understanding risk and send out a key message to these operators that clients are increasingly vigilant towards working practices further down the supply chain. This is one of the most challenging aspects of the social sustainability agenda, and an area that future projects need to embrace and take further.

\section{Rewarding contractors}

In 2013, the decision was made to reward contractors for their sustainability endeavours. To this end, annual sustainability awards were launched with entries invited in the three categories of economic, environmental and social sustainability. This is also very much linked to the project's learning legacy and the sharing of information across the industry. The awards allow contractors to showcase best practice and be recognised for their endeavours. This in turn helps to promote engagement and can help with endorsement when bidding for future work.

The importance of instigating behavioural change was also recognised and a campaign known as 'green line' was initiated. To be awarded a green line, contractors are required to demonstrate above-compliance performance across a number of environmental criteria. The line is a physical and visible symbol at the site entrance to signify a best practice site and promotes pride among the workforce. The above-compliance requirements of recognition under the green line also feed in to the supplier performance framework, thereby providing additional reward. A further stepping 
up of performance allows the contractor to obtain a green line with commendation, providing further motivation for best practice.

\section{Sustainability reporting}

In 2012, Crossrail took the view that it should report publically on its sustainability performance. This was a voluntary decision agreed by its sustainability committee, a sub-committee of the board. Reporting has become an annual process and, broadly in line with global reporting initiative principles, provides a balanced and transparent view of performance against material impacts of the project. The report maintains the holistic approach that the project has taken and covers social, environmental and economic performance.

The value of reporting has been twofold - being open about performance provides focus to targets. If a particular area has been reported on and a need for improvement has been stated, the trajectory of performance is there for all to see in the following year. This acts as an incentive to prioritise actions that will lead to improved performance. This scrutiny and feedback received also provide valuable insight as to whether the correct focus is being placed on the impacts that the stakeholders are interested in and are important to them. If performance is good, the report also provides stakeholders with confidence in the project, thereby supporting the licence to construct.

\section{Innovation}

The project has formed an innovation club with contractors BAM Nuttall, Costain, Dragados, Ferrovial Agroman, Hochtief, Kier, Laing O'Rourke, Morgan Sindall, Murphy, Skanska and Vinci making contributions to jointly invest in innovation at Crossrail. The club supports ideas that have the potential to raise the capability and standards of UK construction.

Crossrail has also partnered with Imperial College London Business School to support research of innovation within temporary organisations, comparing how infrastructure providers are managing and brokering. In return, to inform its strategic approach and key decisions, Crossrail has access to expert advice on innovative management processes and connections to thought leaders on innovation.

The innovation programme provides an environment where individuals can safely exchange ideas across organisational boundaries, collectively build innovative solutions, gain the required support to develop ideas and receive recognition when they are successful. Crossrail's partners at Imperial College London report that this is the world's first innovation programme within a temporary project based organisation.

The programme aims to raise the bar for other construction projects by making innovative ideas, technologies and practices available to the industry as a whole. It is hoped that this will provide confidence to future major programmes to develop and implement an innovation strategy as standard practice.
Since its launch, over 400 ideas have been received, 180 innovations published via a collaboration site and $£ 336910$ invested in 23 ideas. Examples of funded and implemented innovations include low and zero carbon concrete, lightweight aggregate using tunnelling clay, production of supplementary cementitious materials, the use of digital image correlation and photogrammetry to monitor sprayed concrete lined tunnels and an annulus auger pile removal technique. Ideas that do not receive funding are not necessarily without merit - in evaluation, the project's innovation panel represented by supply chain members may decide that the idea has no benefit to the project or their immediate innovation needs.

The innovation programme has very strong links to Crossrail's sustainability strategy by identifying methods of construction, innovative approaches and materials that are all helping to drive down costs, reduce environmental impacts and provide opportunities for the SMEs responsible for much of the innovation in the supply chain. Furthermore, a strong correlation is beginning to emerge between contractors that are able to demonstrate innovation and their overall contract performance.

\section{Summary}

The approach taken on Crossrail demonstrates that an early and clear definition of sustainability with clear lines of ownership, responsibility and governance can be coordinated and managed across diverse interests to provide benefits that are balanced and address social environmental and economic needs. The outcomes from this are demonstrated through the results and confirm the success of this approach, which is commended to other major projects.

On completion, Crossrail will leave a tangible physical legacy, but the intangible legacy of a change in construction industry sustainability performance and the recognition that the benchmark for construction and major projects has been raised could be considered a greater achievement.

Crossrail is paving the way for future projects and is proving that it can be affordable and, indeed, financially and economically beneficial to pursue sustainable outcomes, particularly when wider benefits to the national economy are taken into consideration. The contribution to the economy realised through improved accessibility and journey times are the more direct benefits, but wider benefits such as the opportunities for employment, training and supply chain enhancement are derived through investment in sustainable infrastructure.

\section{Acknowledgements}

The authors thank Crossrail Ltd for permission to publish this paper. Although sustainability on Crossrail is coordinated and managed by the authors, we are indebted to the many individuals on the project who are responsible for the day-to-day management of the project's sustainability portfolio. 
Engineering Sustainability

Volume 168 Issue ES4
Delivering Crossrail, UK: a holistic

approach to sustainability

de Silva and Paris

\section{REFERENCES}

Crossrail Act 2008 (2008) Elizabeth II. Chapter 18. Her Majesty's Stationery Office, London, UK.

GLA (Greater London Authority) (2008) Responsible Procurement Policy. GLA, London, UK.
HM Government (2005) The UK Government Sustainable Development Strategy. HM Government, London, UK.
WHAT DO YOU THINK?

To discuss this paper, please submit up to 500 words to the editor at journals@ice.org.uk. Your contribution will be forwarded to the author(s) for a reply and, if considered appropriate by the editorial panel, will be published as a discussion in a future issue of the journal.

Proceedings journals rely entirely on contributions sent in by civil engineering professionals, academics and students. Papers should be 2000-5000 words long (briefing papers should be 1000-2000 words long), with adequate illustrations and references. You can submit your paper online via www.icevirtuallibrary.com/content/journals, where you will also find detailed author guidelines. 